\title{
Effect of pretreatment of Bacillus subtilis biomass on biosorption and its real time application
}

\author{
Vinay Kumar Chintalapudi ${ }^{1}$, Ramya Krishna S.L. Kanamarlapudi ${ }^{2}$, Useni Reddy Mallu ${ }^{3}$, \\ Sudhamani Muddada ${ }^{*}$ \\ ${ }^{1,3}$ R V Labs, 2-14-117-55, 3rd lane extension, Syamala Nagar, Guntur, Andhra Pradesh, India. \\ ${ }^{2,4}$ Department of Biotechnology, Koneru Lakshmaiah Education Foundation (KLEF), Deemed to be University, Green- \\ fields, Vaddeswaram, Guntur-522502, Andhra Pradesh, India. \\ "Corresponding author: e-mail: sudhamani1@rediffmail.com
}

\begin{abstract}
The research study investigated the biosorption behavior of $\mathrm{Pb}(\mathrm{II})$ ions by treated and untreated biomass of B. subtilis. At initial biosorption conditions, the biosorption efficiency was found to be $36.75 \%$. At the optimized experimental conditions, control biomass showed maximum biosorption efficiency of $58.04 \%$ where the biomass was treated with different chemicals. The biomass treated with formaldehyde showed the highest efficiency of $80.9 \%$ which was further optimized and attained maximum efficiency of $89.8 \%$ for $\mathrm{Pb}$ (II) ions. SEM (Scanning Electron Microscope) and EDX (Energy dispersive X- ray) analysis evaluates the structural and elemental changes that occurred as a result of biosorption. Functional groups that are involved in biosorption were revealed by FTIR (Fourier Transform Infrared spectroscopy). Kinetic data showed the best fit with the pseudo second-order model. Effective removal of lead ions from industrial contaminated water sources by pretreatment biomass of $B$. subtilis elucidates its potential use as biosorbent for metal remediation..
\end{abstract}

Keywords: Effluents, Formaldehyde, Heavy metals, Kinetics, Lead, Microscopic, Pollution.

\section{INTRODUCTION}

One of the global concerns in the environmental field is pollution occurred by heavy metals with the progress in industrial activities that discharges heavy metals into the water streams and poses harmful effects to humans and other forms of life ${ }^{1}$. These metals accumulate and become toxic when present in less concentration. Apart from other metal ions, lead was considered as hazardous and neurotoxic heavy metal ${ }^{2}$. Larger amounts of lead accumulation in various body parts due to industrial discharge results in several health problems like nervous disorders, gastrointestinal damage, sickness and sometimes even death ${ }^{3}$. Hence it is necessary to remove $\mathrm{Pb}$ (II) ions by bringing it to the permissible range of 0.01 $\mathrm{mg} / \mathrm{L}$ as guided by $\mathrm{WHO}^{4}$. Although many conventional methods exist in removing these heavy metals they are associated with many disadvantages and can be less cost-effective in practical use ${ }^{5}$.

Consequently, techniques that are cost-effective and efficient in removing metal ions have to be developed. In this regard, biosorption is possible another biological technique for heavy metal removal with added advantages like high metal-binding ability, environmentally friendly, and biosorbent regeneration with the possible recovery of metal ${ }^{6,7}$. Recently, microorganisms were used as biosorbents for metal removal ${ }^{8-10}$. The occurrence of numerous active sites on microorganism surfaces makes there use as biosorbents in the remediation of metals from water resources in various studies ${ }^{11,12}$.

In recent years pretreatment of biomass by different methods was developed to increase biosorbent efficiency. Since biosorption implies the availability of metal-binding sites, pretreatment will modify the biosorbent surface features by increasing the available sites which as a result influences the increase in biosorption efficiency ${ }^{13}$.

Hence, the study focuses on the utilization of $B$. subtilis as biosorbent for $\mathrm{Pb}(\mathrm{II})$ ion biosorption under optimized conditions. The impact of pretreatment with various chemicals and optimization of biosorption conditions to increase the biosorption efficiency for pretreated $B$. subtilis was studied for the first time in literature. Batch biosorption studies to determine the maximum biosorption efficiency of both control and treated biomass of $B$. subtilis for $\mathrm{Pb}(\mathrm{II})$ ions was evaluated. SEM-EDX, FTIR, and kinetic studies were done to evaluate the biosorption changes.

\section{MATERIALS AND PREPARATION METHODOLOGY}

\section{Microbial strain and growth}

Bacillus subtilis (1427) having lead reducing activity was obtained from Microbial Type Culture Collection (MTCC), Chandigarh. On the fresh slants of growth medium (beef extract $1.0 \mathrm{~g}$, yeast extract $2.0 \mathrm{~g}$, peptone $5.0 \mathrm{~g}$, agar $15.0 \mathrm{~g}$, and sodium chloride $5.0 \mathrm{~g}$ in $1.0 \mathrm{~L}$ of distilled water) bacteria was streaked and incubated at $37^{\circ} \mathrm{C}$ for $24-48 \mathrm{~h}$. The bacterium slants were subculture at regular intervals every 30 days by maintaining at $4^{\circ} \mathrm{C}$.

\section{Inoculum preparation}

The inoculum was prepared from the freeze slant by incubating at $25^{\circ} \mathrm{C}$ for 7 days. Then the slant was washed after sporulation into the culture medium by using autoclaved deionized water and resulted in suspension was filtered by using sterile cheese cloth (several layers). The spore density of the obtained inoculum suspension was adjusted to $2 \times 10^{8}$ numbers per $\mathrm{mL}$ and used for propagating the bacterium for further biosorption experiments.

\section{Preparation of metal stock solutions}

Weigh accurate quantity of lead nitrate $(159.8456 \mathrm{mg})$ and dissolve in $0.1 \mathrm{~L}$ of double distilled water to attain standard stock solution of lead with a final concentration of $1000 \mu \mathrm{g} / \mathrm{mL}$ by diluting the stock, working concentrations were prepared. 


\section{Cultivation and Preparation of microorganism for bio- sorption}

Into the growth medium (Nutrient broth) B. subtilis was inoculated and incubated at $37^{\circ} \mathrm{C}$ for 5 days at 100 rpm. After incubation, the biomass obtained by centrifugation was purified by washing with sterile distilled water. At $60^{\circ} \mathrm{C}$ the biomass was dried for $24 \mathrm{~h}$ and used for experiments.

\section{Pre-treatment of biomass}

The biomass of $B$. subtilis was treated with five different chemicals. The following chemical solutions $(100 \mathrm{~mL})$ were used for pre-treatment of biomass:

$-0.1 \mathrm{M}$ oxalic acid;

- $0.1 \mathrm{M}$ calcium chloride;

- $0.1 \mathrm{M}$ sodium carbonate;

- $10 \%$ hydrogen peroxide solution and

- Commercially available formaldehyde solution.

To each of the prepared chemical solutions, $1 \mathrm{~g}$ of powdered B. subtilis biomass was treated for $30 \mathrm{~min}$. After incubation, the biomass of each treatment was separated, washed and dried for use.

\section{Biosorption experiments}

Biosorption experiments for the control biomass of $B$. subtilis (without any pretreatment) were performed in $250 \mathrm{~mL}$ Erlenmeyer flasks by dissolving $1 \mathrm{~g}$ of biomass with lead ion concentration of $50 \mu \mathrm{g} / \mathrm{mL}$ and agitated with $40 \mathrm{rpm}$ for $16 \mathrm{~h}$ at $35^{\circ} \mathrm{C}$ after adjusting the $\mathrm{pH}$ to 6.5. To attain the maximum biosorption efficiency of control biomass, various experimental conditions $(\mathrm{pH}$, temperature, incubation time, inoculum dosage and agitation speed) were optimized.

At the optimized biosorption conditions of control biomass (where it has shown the maximum biosorption capacity), biosorption experiments were conducted for B. subtilis after treated with different chemicals. Experimental conditions for the treated biomass which showed the highest biosorption were further optimized to attain the maximum biosorption efficiency.

After incubation at respective experimental conditions, the contents of the entire flasks were separated by centrifugation (4000 rpm, $3 \mathrm{~min}$ ) and supernatants were collected to determine the residual lead ions by Inductive Coupled Plasma Optical Emission Spectrometry (ICP-OES). The optimized operating conditions of ICP-OES that are given the best results are RF power $-1100 \mathrm{~W}$, cool gas flow $-12.5 \mathrm{~L} / \mathrm{min}$, auxiliary gas flow $-0.9 \mathrm{~L} /$ min with a nebulizer gas flow of $0.265 \mathrm{~L} / \mathrm{min}$.

Determination of biosorption capacity $\left(\mathrm{q}_{\mathrm{e}}\right)$ of biomass was done by applying the equation:

$q e=\frac{(C i-C e) V}{m}$

Where $\mathrm{q}_{\mathrm{e}}$ is the amount of metal biosorbed to the biosorbent $\left(\mathrm{mg} \mathrm{g}^{-1}\right), \mathrm{C}_{\mathrm{i}}$ is the initial metal ion concentration in solution $\left(\mathrm{mg} \mathrm{L}^{-1}\right), \mathrm{C}_{\mathrm{e}}$ is the residual metal concentration in the supernatant $\left(\mathrm{mg} \mathrm{L}^{-1}\right), \mathrm{V}$ is the volume of the medium $(\mathrm{L})$, and $\mathrm{m}$ is the amount of the biomass used in the biosorption process $(\mathrm{g})$.

The biosorption potential (\%) was determined by the equation:

$\%$ of biosorption $=\frac{\mathrm{Ci}-\mathrm{Ce}}{\mathrm{Ci}} \times 100$
Scanning Electron Microscope and Energy Dispersive X-ray (SEM-EDX) analysis

Morphological and structural changes that occurred as a result of lead biosorption were evaluated by using CARL ZEISS SUPRA 55 GEMIN (German Technology Jena, Germany) Scanning Electron Microscope (SEM). For this, the samples of the biomass were applied on metal stubs after glutaraldehyde fixation and drying. The samples were then sputtered with gold (SC7620 'Mini' sputter coater) and observed. Mapping of metal ions (distribution) and elemental analysis were performed by Energy Dispersive X-ray analyzer. The X-ray spectrum of each loaded sample was acquired at $16 \mathrm{KeV}$ acceleration voltages.

\section{Fourier Transform Infrared Spectroscopy (FTIR) analysis}

Determine of functional groups and their chemical modifications occurred as a result of biosorption was analyzed by FTIR spectroscopy. For analysis, KBr discs containing dried biomass and potassium bromide in 1:100 ratios were prepared and analyzed by recording the spectra within $4000-500 \mathrm{~cm}^{-1}$ range and $4 \mathrm{~cm}^{-1}$ resolution.

\section{Biosorption Kinetics}

Pseudo first and second-order kinetic models were used for the prediction of mechanism and biosorption rate between metal-binding sites and metal ions.

The linear form of the pseudo first-order model is expressed by the following equation:

$\log \left(q_{e}-q_{t}\right)=\log q_{t}-\frac{k_{1} t}{2.303}$

The linear form of the pseudo second-order model is expressed by the following equation:

$\frac{t}{q_{t}}=\frac{1}{k_{2} \cdot q_{e}^{2}}+\frac{t}{q_{e}}$

Where $\mathrm{q}_{\mathrm{e}}$ and $\mathrm{q}_{\mathrm{t}}$ are the amount of metal ion biosorbed at equilibrium and at time $\mathrm{t}$ respectively, $(\mathrm{mg} / \mathrm{L})$, $\mathrm{k}_{1}$ is the pseudo first-order rate constant (per min) and $\mathrm{k}_{2}$ is the pseudo second-order rate constant (per min). The parameters of pseudo first and second-order kinetic models can be calculated from the linear plots of $\log$ $\left(\mathrm{q}_{\mathrm{e}}-\mathrm{q}_{\mathrm{t}}\right)$ versus $\mathrm{t}$, and $\mathrm{t} / \mathrm{q}_{\mathrm{t}}$ versus $\mathrm{t}$, respectively.

\section{Statistical analysis}

Triplicate data were obtained for each experiment and statistical analysis was performed by one way Annova. Graph Pad Prism 5 was used for plotting the graphs expressing mean \pm standard deviation values.

\section{RESULTS AND DISCUSSION}

B. subtilis is recognized as GRAS organism in recent years ${ }^{\mathbf{1 4}}$ and also pretreatment of biomass with different chemicals enhanced the biosorption efficiency which makes its use as an effective biosorbent in metal ion removal. Since scanty information is available regarding the use of treated biomass of $B$. subtilis in biosorption studies, hence its role is also discussed in the present study. 


\section{Biosorption studies}

Based on ICP-OES result, at initial biosorption conditions, the biosorption efficiency of B. subtilis was $36.75 \%$. Hence various experimental parameters were optimized to attain the maximum biosorption efficiency.

At the optimized experimental conditions (which was described below), the biosorption efficiency was increased to $58.05 \%$ with a lead ion concentration of $50 \mu \mathrm{g} / \mathrm{mL}$, at $\mathrm{pH} 6.5$ with biosorbent dose of $1.5 \mathrm{~g}$ incubated at $35^{\circ} \mathrm{C}$ for $16 \mathrm{~h}$ at $40 \mathrm{rpm}$. Similar results were obtained with other metal ions using $B$. subtilis as biosorbent with biosorption efficiency of $60 \%$ for $\mathrm{Cr}(\mathrm{VI})^{\mathbf{1 5}}$ and $63.73 \%$ for $\mathrm{Zn}(\mathrm{II})$ ions $^{\mathbf{1 6}}$ at optimized conditions. Some studies reported that the highest biosorption efficiency of $98.4 \%$ and $90 \%$ was achieved for $\mathrm{Pb}$ (II) ions using B. subtilis and $B$. cereus as biosorbents respectively ${ }^{17},{ }^{18}$. Further to increase the biosorption efficiency the biomass of $B$. subtilis was treated with different chemicals. At optimized biosorption conditions of control biomass, biomass treated with formaldehyde (Fig. 1) showed the highest efficiency of $80.92 \%$ when compared with the other treatments and control $(58.05 \%)$. Further optimization of experimental parameters was conducted to attain the maximum biosorption efficiency for the treated biomass.

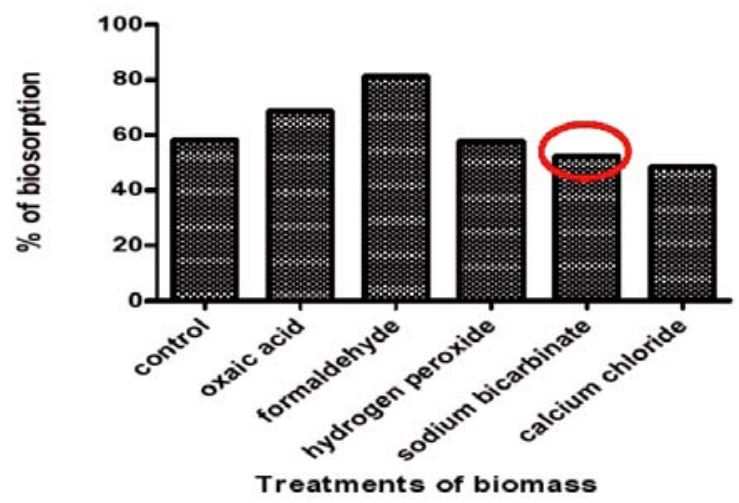

Figure 1. Effect of pretreatment on biosorption efficiency of B. subtilis for $\mathrm{Pb}(\mathrm{II})$ when treated with different chemicals

\section{Optimization studies}

Various experimental parameters were optimized for both control (untreated) and treated biomass of $B$. subtilis to increase the efficiency of biosorption.

\section{Effect of $\mathrm{pH}$}

The study of $\mathrm{pH}$ is essential for the determination of the surface charge of biosorbent for metal ion biosorption. Figure $2 \mathrm{a}$ and $\mathrm{b}$ show the effect of $\mathrm{pH}$ for both control and treated biomass of $B$. subtilis within the range of 4-7.5. At acidic conditions, the efficiency of biosorption was low, reaches the maximum at $\mathrm{pH} 6.5$ and declines in the alkaline conditions. The phenomenon is due to at low $\mathrm{pH}$, more protons exist which competes with the existing metal ions thus decreasing the biosorption efficiency. With the increase in $\mathrm{pH}$, protons get deprotonated making the biosorbent negatively charged which attracts the metal ions and reaches the maximum. At high $\mathrm{pH}$ values, metal hydroxides are formed due to the occurrence of more $\mathrm{OH}^{-}$ions and results in decrement of biosorption efficiency. Hence pH 6.5 was considered a
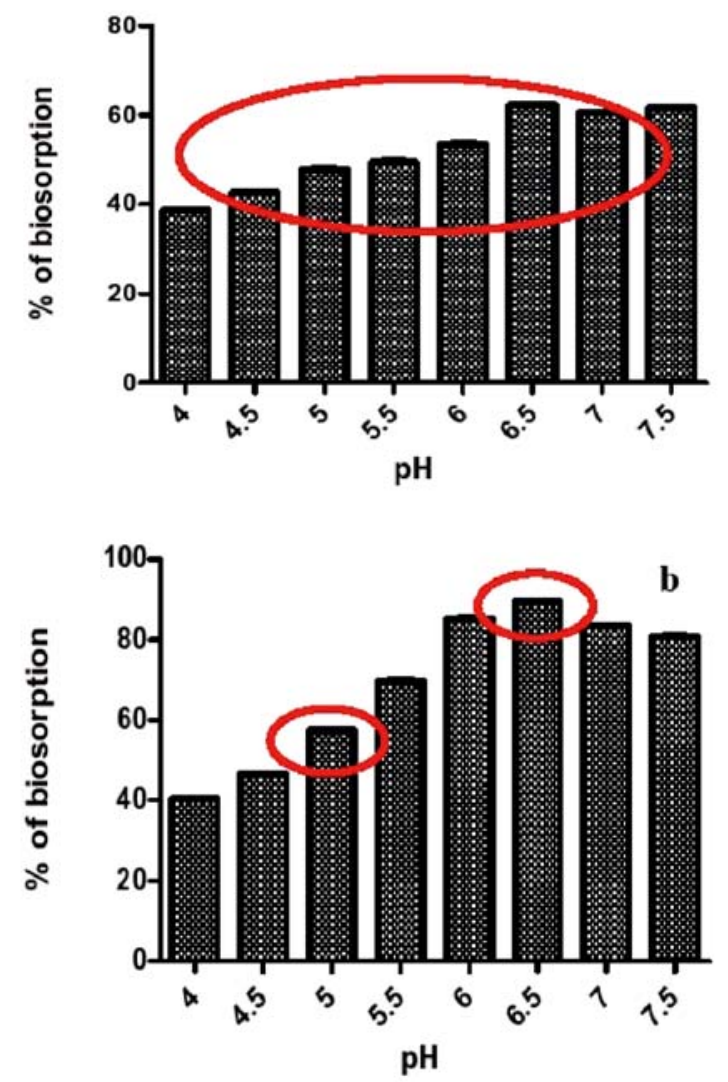

Figure 2. Effect of $\mathrm{pH}$ on biosorption of $\mathrm{Pb}(\mathrm{II})$ by control (a) and formaldehyde (b) treated biomass of $B$. subtilis

as optimum with high biosorption efficiency of $62 \%$ and $89 \%$ for control and treated biomass of B. subtilis respectively. A similar effect of $\mathrm{pH}$ was observed with B. pumilus for $\mathrm{Pb}(\mathrm{II})$ ion biosorption with the highest efficiency at $\mathrm{pH} 6.0^{19}$.

\section{Effect of contact time}

Figure $3 \mathrm{a}$ and $\mathrm{b}$ represents the $\mathrm{Pb}(\mathrm{II})$ ion biosorption with time for control and treated biomass of B. subtilis. From the results, the rate of biosorption was rapid and maximum within the first $16 \mathrm{~h}$ of contact time which is followed by a slower or saturated stage of biosorption with a further increase in time to $48 \mathrm{~h}$. The reason for the highest efficiency is due to the availability of abundant metal-binding sites. Thereafter competition exists for occupying the available binding sites with the metal ion which results in a slower rate of biosorption. Also in practical applications, the treatment of biomass for longer periods will be uneconomical and power wasting ${ }^{20}$ and hence contact time of $16 \mathrm{~h}$ was taken as optimum with maximum biosorption efficiency of $59.83 \%$ and $80.79 \%$ for control and treated biomass of $B$. subtilis respectively. A similar result was observed with Pseudomonas aeruginosa and B. cereus in biosorption of $\mathrm{Zn}(\mathrm{II})$ ions ${ }^{\mathbf{2 1}}$.

\section{Effect of Biosorbent dose}

Figure $4 \mathrm{a}$ and $\mathrm{b}$ shows the impact of biosorbent dose on $\mathrm{Pb}(\mathrm{II})$ ion biosorption with control and treated biomass. With the increase in biosorbent dose, the efficiency of biosorption was also increased up to $1.5 \mathrm{~g} / \mathrm{L}$. Afterward 

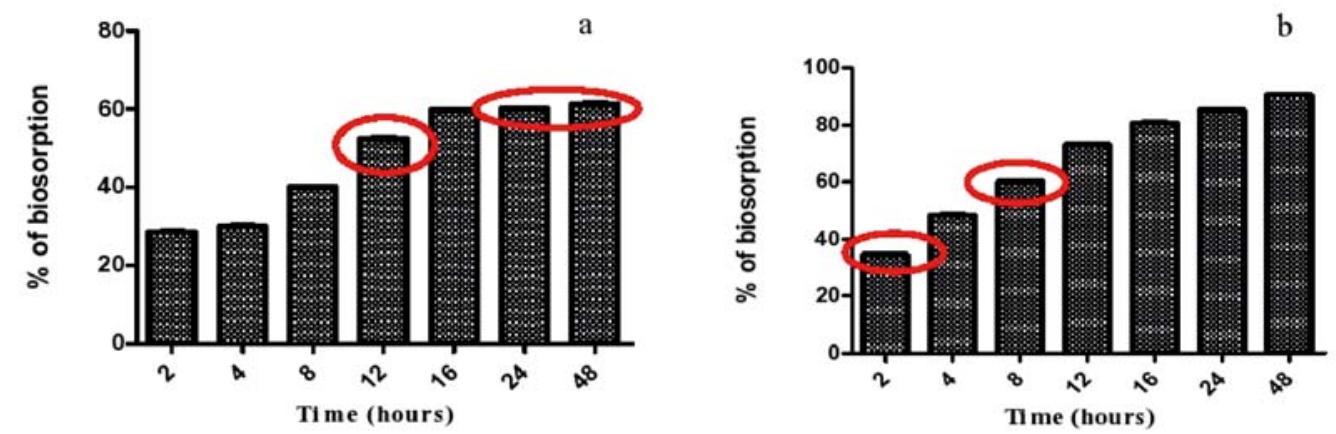

Figure 3. Effect of contact time on biosorption of $\mathrm{Pb}(\mathrm{II})$ by control (a) and formaldehyde (b) treated biomass of $B$. subtilis
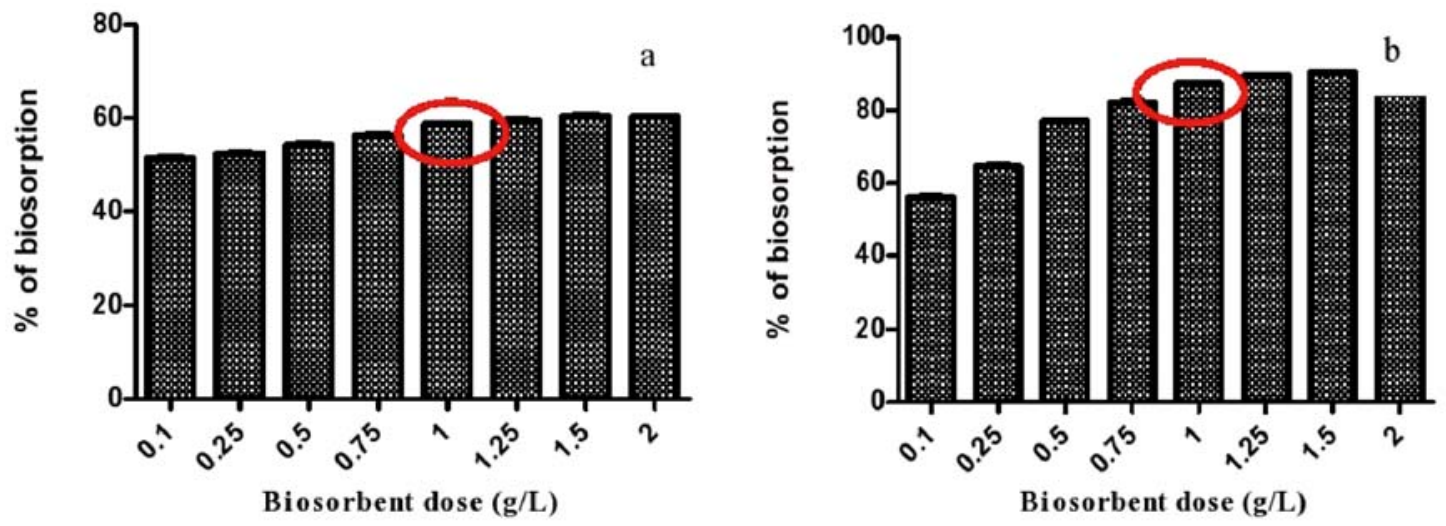

Figure 4. Effect of biosorbent dose on biosorption of $\mathrm{Pb}(\mathrm{II})$ by control (a) ans formaldehyde (b) treated biomass of B. subtilis

the biosorption efficiency was decreased or remains constant. An increase in biosorption at the initial biosorbent dose is due to the presence of a larger surface area that results in an increase of available active sites for metal ions. At higher biosorbent dose aggregate formation or overlapping of the biosorbent surface occurs that reduces the surface area for biosorption and results in lower biosorption efficiency. Hence biosorbent dose of $1.5 \mathrm{~g}$ was found to be optimum for control and treated biomass of $B$. subtilis with biosorption efficiencies of $60.4 \%$ and $90.4 \%$ respectively. Recent studies show that Citrobacter freundii and Klebsiella pneumonia achieved maximum biosorption efficiency for $\mathrm{Pb}(\mathrm{II})$ ions when biosorbent dose of $2 \mathrm{~g} / \mathrm{L}$ was used ${ }^{2}$.

\section{Effect of temperature}

$\mathrm{Pb}(\mathrm{II})$ ion biosorption by control and treated biomass of $B$. subtilis with temperature was given in Figure 5a and $\mathrm{b}$. With the increase in temperature from $25^{\circ} \mathrm{C}$ to $60^{\circ} \mathrm{C}$, the efficiency of biosorption decreased with the maximum at $35^{\circ} \mathrm{C}$. An increase in temperature enhances the rate of biosorption due to increased solute kinetic energy and surface activity. Higher temperatures result in deactivation or damage to the metal active sites present on biosorbent surface which results in rupturing of the bonds and a decrease in biosorption efficiency. Also at high temperatures, it is expected that physical damage can occur to the biosorbent. Hence $35^{\circ} \mathrm{C}$ was considered as optimum with maximum biosorption efficiency of $51 \%$ and $89 \%$ for control and treated biomass of $B$. subtilis respectively. Similarly, the maximum biosorption efficiency of $92 \%$ for $\mathrm{Fe}(\mathrm{II})$ at $30^{\circ} \mathrm{C}$ and $94 \%$ for $\mathrm{Cu}(\mathrm{II})$ ions at $45^{\circ} \mathrm{C}$ was achieved by Bacillus licheniformis ${ }^{22}$.

\section{Effect of agitation speed}

Figure $6 \mathrm{a}$ and $\mathrm{b}$ shows that the optimum agitation speed was $40 \mathrm{rpm}$ with maximum biosorption efficiency of $58 \%$ and $87 \%$ for control and treated biomass of B. subtilis. Agitation speed is an important parameter for biosorption since it expands the interaction possible between the metal and biomass. Settling of biomass can be observed at low speed which results in the burying
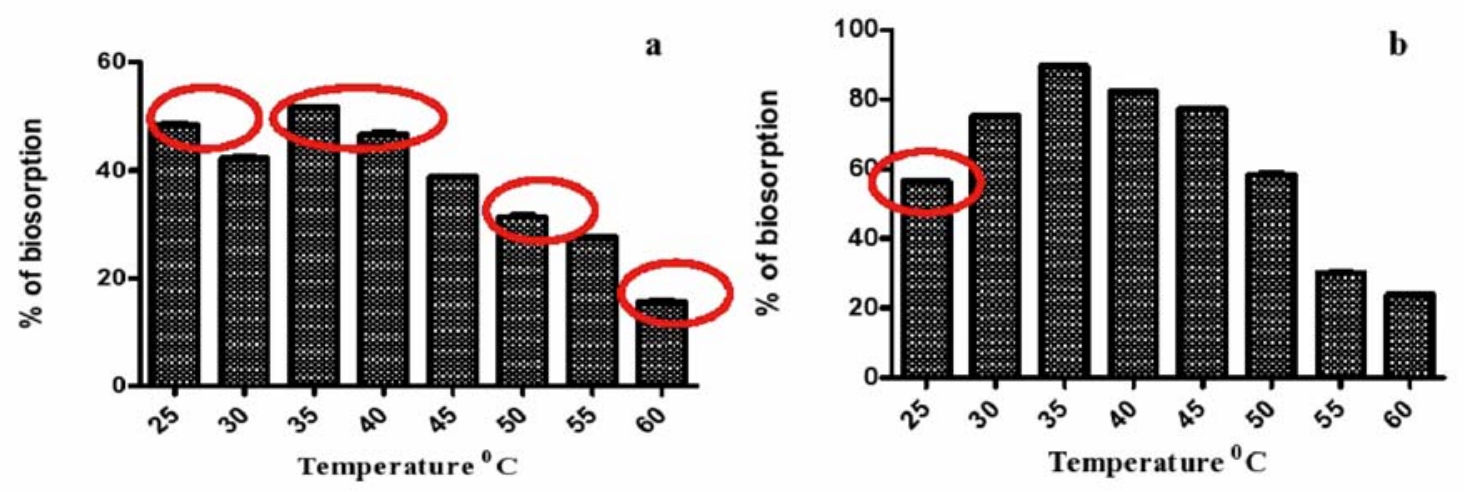

Figure 5. Effect of temperature on biosorption of $\mathrm{Pb}(\mathrm{II})$ by control (a) and formaldehyde (b) treated biomass of B. subtilis 

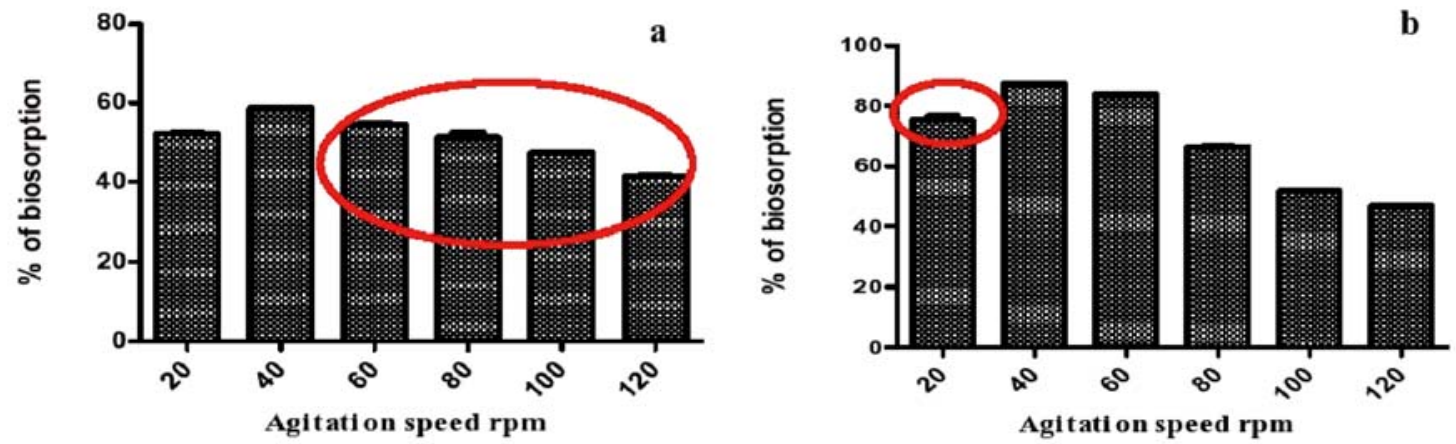

Figure 6. Effect of agitation on biosorption of $\mathrm{Pb}(\mathrm{II})$ by control (a) and formaldehyde (b) treated biomass of $B$. subtilis

of metal-binding sites. Hence the sites available on the upper region of the biosorbent take part in biosorption process that results in lower efficiency. At high agitation speeds, due to the occurrence of random collisions between the biosorbent and biosorbate the time required to interact with the binding sites of biosorbent decreases which also results in low efficiency. Hence in the present study, the agitation speed of $40 \mathrm{rpm}$ was recognized as optimum. Studies also showed that $80 \mathrm{rpm}$ was optimum to attain a maximum efficiency of biosorption for $\mathrm{Cd}(\mathrm{II})$ ions by Klebsiella $\mathrm{sp}^{23}$.

\section{Effect of pretreatment}

At the optimized experimental conditions the biosorption efficiency of formaldehyde-treated $B$. subtilis biomass was increased to $89.8 \%$ with $50 \mu \mathrm{g}$ metal ion, $1.5 \mathrm{~g} / \mathrm{L}$ of biosorbent dose at $\mathrm{pH} 6.5$ for $16 \mathrm{~h}$ incubated at $35^{\circ} \mathrm{C}$ with $40 \mathrm{rpm}$. Thus the data indicate that the pretreatment enhances the efficiency of biosorbent for lead ion biosorption. Studies reported that pretreatment with different chemicals modifies the surface of the biomass either by masking or removing the surface impurities ${ }^{24}$ and rupturing of cell membrane that results in the availability of more metal binding sites ${ }^{25}$ which are the reasons for the increased biosorption. No reports of formaldehyde treated bacterial biomass for lead biosorption were found. However, a maximum biosorption capacity of $774 \mathrm{mg} / \mathrm{g}$ for $\mathrm{Pb}(\mathrm{II})$ was observed with red marine algae Jania ruben when pretreated with formaldehyde compared to the raw biomass $(696 \mathrm{mg} / \mathrm{g})^{26}$. Also, the fungal biomasses of Aspergillus versicolor, Metarrhizium anisopliae var. anisopliae and Pencillium verrucosum showed biosorption capacity of 22, 12.4 and $5.4 \mathrm{mg} / \mathrm{g}$ for $\mathrm{Pb}$ (II) ions which was increased to 23.1, 18.1 and $18.7 \mathrm{mg} / \mathrm{g}$ after formaldehyde treatment respectively ${ }^{27}$.

\section{SEM-EDX analysis}

Figure 7a and 8a evaluate the morphological changes of control and $\mathrm{Pb}$ (II) biosorbed B. subtilis biomass. SEM images reveal that in the control biomass smooth and elongated cells are visible in loosely bound form. Following biosorption, the cells became small and puffy due to lead deposition. The results are also in accordance with EDX analysis. By comparing the elemental composition (Fig. 7b and 8b), and EDX spectra (Fig. 7c and 8c) the changes in the percentage composition of the elements and a peak for $\mathrm{Pb}(\mathrm{II})$ in the treated biomass confirms that the $\mathrm{Pb}$ (II) ions were biosorbed on to $B$. subtilis by ion-exchange mechanism. Similar changes in morphology and EDX spectra due to biosorption with metal ions were observed by other bacterial biosorbents ${ }^{28,29}$.

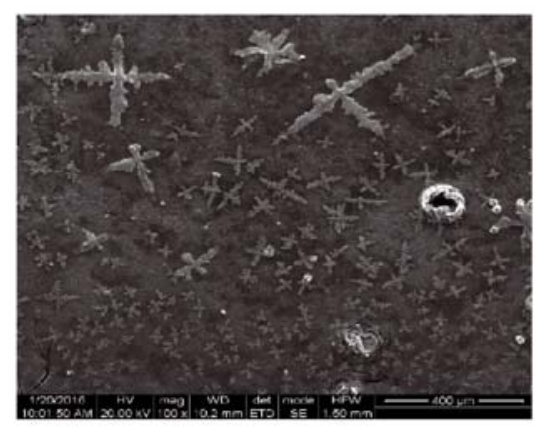

\begin{tabular}{|c|c|c|}
\hline Element & $\mathrm{W} 1 \%$ & $\mathrm{~A} \%$ \\
\hline $\mathrm{C}$ & 53.27 & 68.12 \\
\hline $\mathrm{O}$ & 17.23 & 16.54 \\
\hline $\mathrm{Na}$ & 11.10 & 07.42 \\
\hline $\mathrm{Cl}$ & 17.21 & 07.46 \\
\hline $\mathrm{K}$ & 01.20 & 00.47 \\
\hline
\end{tabular}

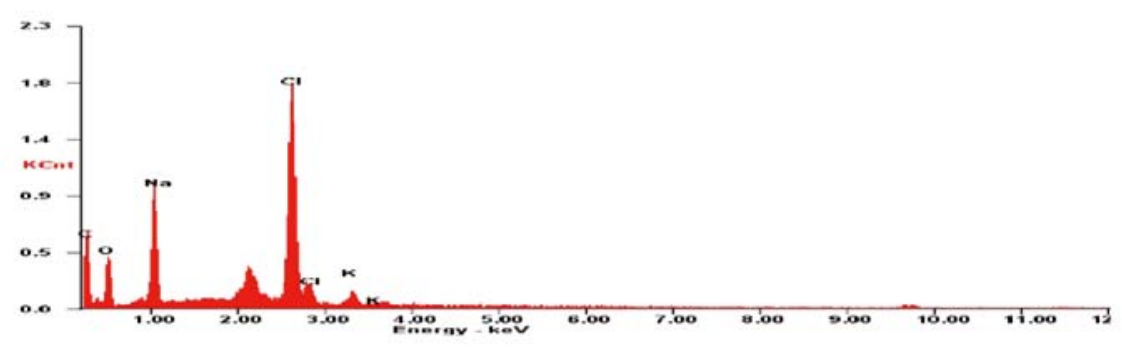

Figure 7. SEM image, elemental composition and EDX spectra of control biomass of B. subtilis 


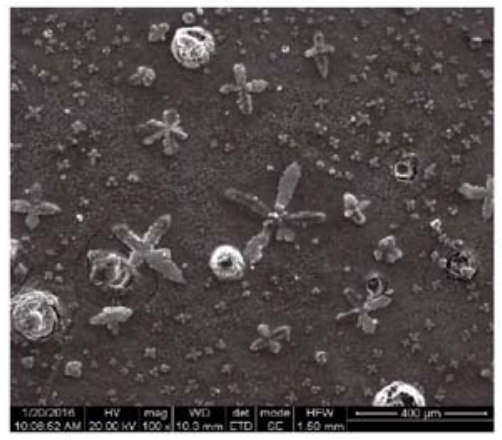

\begin{tabular}{|c|c|c|}
\hline Element & $\mathrm{Wt} \%$ & $\mathrm{At} \%$ \\
\hline $\mathrm{C}$ & 41.15 & 73.47 \\
\hline $\mathrm{O}$ & 16.06 & 21.53 \\
\hline $\mathrm{Na}$ & 00.17 & 00.16 \\
\hline $\mathrm{Cl}$ & 00.86 & 00.52 \\
\hline $\mathrm{K}$ & 00.00 & 00.00 \\
\hline $\mathrm{Pb}$ & 41.76 & 04.32 \\
\hline
\end{tabular}

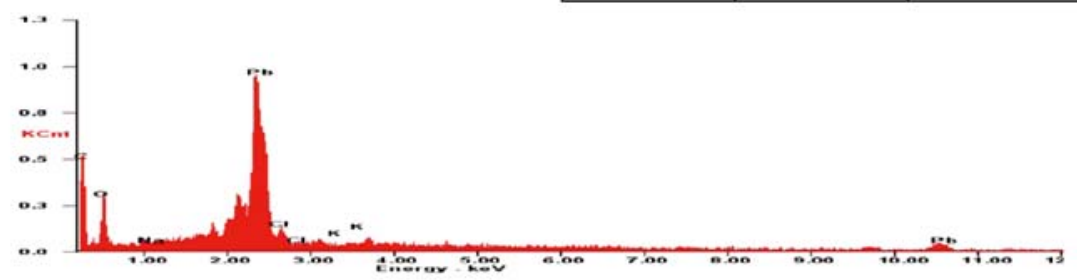

Figure 8. SEM image, elemental composition and EDX spectra of $\mathrm{Pb}(\mathrm{II})$ biosorbed biomass of $B$. subtilis

\section{FTIR analysis}

FTIR study enables one to examine the surface characterization of biosorbent as a result of chemical modification and biosorption and determination of functional groups that participate in biosorption process.

Figure 9a and $\mathrm{b}$ show the spectra of control (untreated) and treated biomass of $B$. subtilis. The bands at $3344.78 \mathrm{~cm}^{-1}$ (control) and 3857.72, $3748.40,3332.58 \mathrm{~cm}^{-1}$ (treated) indicates the presence of $-\mathrm{OH}$ stretching of polymeric compounds and -NH stretching of proteins. The peaks at $2117.93 \mathrm{~cm}^{-1}$ (control) and 2919.87, 2115.77 $\mathrm{cm}^{-1}$ (treated) contributes to C-H stretching vibrations of aliphatic groups $\left(\mathrm{CH}_{2}\right.$ and $\left.\mathrm{CH}\right)$. The peaks at 1636.43 (control) and $1632.59 \mathrm{~cm}^{-1}$ (treated) corresponds to $\mathrm{C}=\mathrm{C}$ and $\mathrm{C}=\mathrm{O}$ vibration respectively. The peaks at 1342.51

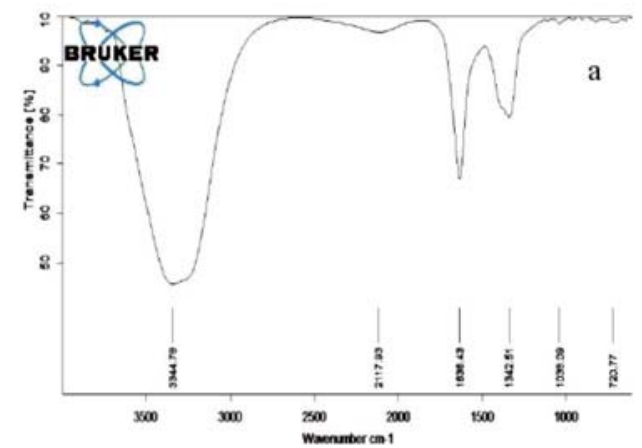

$\mathrm{cm}^{-1}$ (control) and $1325.8 \mathrm{~cm}^{-1}$ (treated) are due to phosphate group vibration. The peaks at $1038.09 \mathrm{~cm}^{-1}$ (control) and $1034.34 \mathrm{~cm}^{-1}$ (treated) correlate to C-O$-\mathrm{C}$ and $\mathrm{O}-\mathrm{H}$ stretching vibration of polysaccharide like substance. The peaks at $720.77,872.30,668.3 \mathrm{~cm}^{-1}$ are indicative of finger print zone which contains phosphate and sulfur functional groups. Treated biomass shows an extra peak at $1150.64 \mathrm{~cm}^{-1}$ correspondings to $-\mathrm{S}=\mathrm{O}$ stretching. The above comparison concludes that additional peaks are formed on the surface of $B$. subtilis biomass due to pretreatment which indicates the increase for biosorption efficiency.

Figure $10 \mathrm{a}$ and $\mathrm{b}$ shows the spectra after $\mathrm{Pb}(\mathrm{II})$ ion biosorption of control and treated biomass of B. subtilis. Comparing Figure 9a and 10a, a shift in the peak

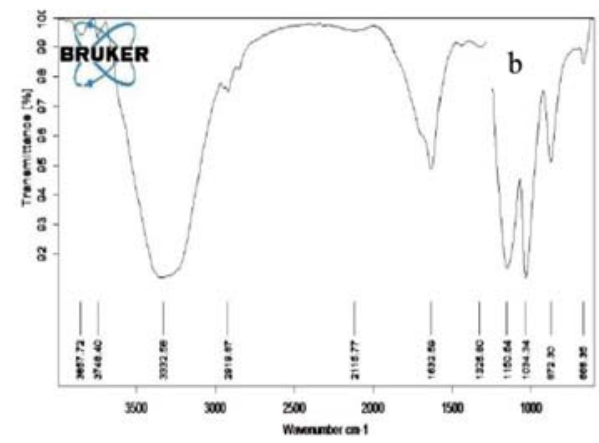

Figure 9. FTIR spectra of control (a) and formaldehyde (b) treated biomass of B. subtilis
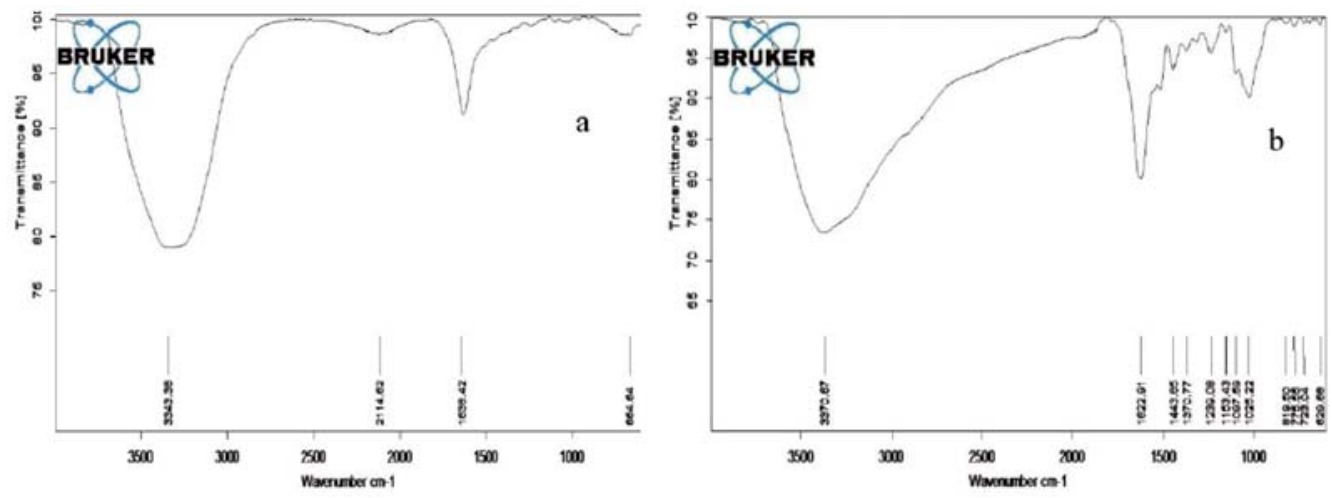

Figure 10. FTIR spectra of $\mathrm{Pb}(\mathrm{II})$ biosorbed control (a) and formaldehyde (b) treated biomass of B. subtilis 
intensities to $3343.38,2114.62,1638.42,664.64 \mathrm{~cm}^{-1}$ in the control biomass biosorbed with lead was noticed. Similarly, a shift to $3370.67,1622.91,1370.77,1153.43$, $1097.59,10.25 .22819 .50,629.68 \mathrm{~cm}^{-1}$ in the treated biomass biosorbed with lead was observed (Fig. 9b and 10b). The shifts indicate that the functional groups present at these regions are involved in biosorption process to interact with metal ions. Appearance (1443.85, 1239.08, $\left.775.55,723.04 \mathrm{~cm}^{-1}\right)$ and disappearance $(2919.87,2115.77$ $\mathrm{cm}^{-1}$ ) of peaks in the treated biomass indicates the interaction with lead ions (Fig. $9 \mathrm{~b}$ and $10 \mathrm{~b}$ ). Hence, it can be concluded that the functional groups hydroxyl, amino and carboxyl that are present on $B$. subtilis biomass surface take part in metal ion biosorption. This is in accordance with other results obtained by Bacillus thuringiensis for the biosorption of $\mathrm{Cd}(\mathrm{II}), \mathrm{Cr}(\mathrm{VI}), \mathrm{Cu}(\mathrm{II}), \mathrm{Pb}(\mathrm{II})$ and $\mathrm{Ni}(\mathrm{II})^{30}$ and Bacillus sp. for the biosorption of $\mathrm{Cr}(\mathrm{VI})$ and $\mathrm{Cu}(\mathrm{II})$ ions $^{31}$.

\section{Biosorption Kinetics}

Evaluation of sorption kinetics describes the behavior of lead ion biosorption onto B. subtilis biomass. Table 1 summarizes the constants and correlation coefficients $\left(\mathrm{R}^{2}\right)$ obtained from the plots of kinetic models. Based on correlation coefficients values, it shows that the data were fitted well with the pseudo second-order kinetic model for both untreated $\left(\mathrm{R}^{2}=0.9753\right)$ and treated $\left(\mathrm{R}^{2}=0.9956\right)$ biomass of $B$. subtilis. Thus it indicates that the rate limiting step in biosorption is chemisorption with the involvement of covalent forces either by sharing or by the exchange of electrons between the metal ions and the surface functional groups of the biosorbent. Similarly, other studies show that the biosorption of $\mathrm{Cu}$ (II) ions by Bacillus subtilis ${ }^{32}$ and $\mathrm{Pb}(\mathrm{II}), \mathrm{Cr}(\mathrm{III})$, and $\mathrm{Cu}(\mathrm{II})$ by Rhodococcus opacus ${ }^{\mathbf{3 3}}$ obeys the pseudo second-order kinetic model as the better fit.

\section{Real time studies}

Real water samples from streams and lakes near contaminated industrial sites located at Autonagar, Budampadu and Takkellapadu towns of Guntur district were collected for application of pretreatment biomass of B. subtilis for lead removal. Twenty samples labeled as RTS0-RTS20 were collected in wide mouth $1 \mathrm{~L}$ capacity bottles and stored at room temperature for analysis. Collected water samples were chemically analyzed for $\mathrm{pH}$, temperature $\left({ }^{\circ} \mathrm{C}\right)$, electric conductivity $(\mu \mathrm{mos} / \mathrm{cm})$, total alkalinity $(\mathrm{mg} / \mathrm{L})$ and turbidity according to standard methods of IS: $3015^{\mathbf{3 4}}$ and summarized in Table 2. Metal concentration was determined by ICP-OES and the samples with a high concentration of metal were subjected to biosorption experiments by pretreatment biomass of $B$. subtilis at optimized experimental conditions. Figure 11 elucidates that the biomass of $B$. subtilis removed lead ions efficaciously in the range of $16.6 \%$ to $53 \%$ for

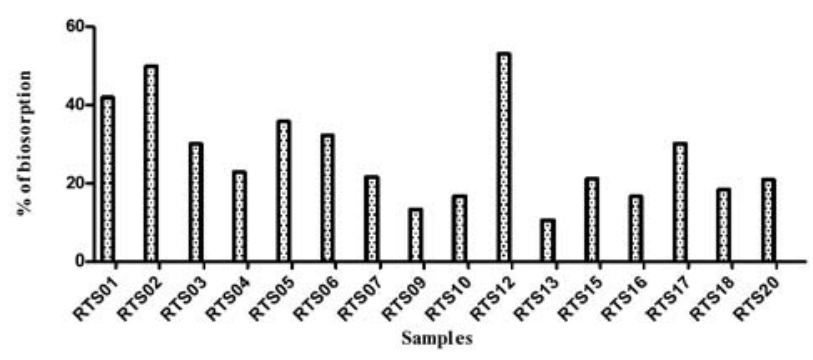

Figure 11. Percentage biosorption of lead ions from the contaminated wastewater samples by pretreated biomass of B. subtilis at optimized conditions

Table 1. Parameters of pseudo first and second order kinetic models for the biosorption of $\mathrm{Pb}$ (II) ions onto untreated (control) and treated biomass of $B$. subtilis

\begin{tabular}{|c|c|c|c|c|c|c|}
\hline Treatments & \multicolumn{3}{|c|}{ Pseudo first order kinetic model } & \multicolumn{3}{|c|}{ Pseudo second order kinetic model } \\
\hline & $\mathrm{q}_{\mathrm{e}}(\mathrm{mg} / \mathrm{g})$ & $\mathrm{K}_{1}\left(\mathrm{~min}^{-1}\right)$ & $\mathrm{R}^{2}$ & $\mathrm{q}_{\mathrm{e}}(\mathrm{mg} / \mathrm{g})$ & $\mathrm{K}_{2}\left(\mathrm{gmg}^{-1} \mathrm{~min}^{-1}\right)$ & $\mathrm{R}^{2}$ \\
\hline $\begin{array}{c}\text { Control biomass } \\
\text { (Untreated) }\end{array}$ & 28.33 & 0.173 & 0.9078 & 36.36 & 0.0058 & 0.9753 \\
\hline Treated Biomass & 33.596 & 0.109 & 0.9888 & 50.50 & 0.0045 & 0.9956 \\
\hline
\end{tabular}

Table 2. Physicochemical parameters of collected wastewater samples

\begin{tabular}{|c|c|c|c|c|c|c|c|c|}
\hline S.No & $\begin{array}{l}\text { Sample } \\
\text { code }\end{array}$ & $\mathrm{pH}$ & $\begin{array}{c}\text { Temperature in } \\
{ }^{\circ} \mathrm{C}\end{array}$ & $\begin{array}{c}\mathrm{EC} \text { in } \\
\mu \mathrm{mos} / \mathrm{cm}\end{array}$ & $\begin{array}{c}\text { Total } \\
\text { alkalinity as } \\
\mathrm{mg} / \mathrm{L}\end{array}$ & $\begin{array}{c}\text { Turbidity in } \\
\text { NTU }\end{array}$ & $\begin{array}{c}\text { Initial lead } \\
\text { concentration } \\
(\mathrm{mg} / \mathrm{L})\end{array}$ & $\begin{array}{c}\text { Final } \\
\text { concentration of } \\
\text { lead }(\mathrm{mg} / \mathrm{L})\end{array}$ \\
\hline 1 & RTS01 & 8.5 & 24 & 2435 & 796 & 0.9 & 0.31 & 0.18 \\
\hline 2 & RTS02 & 8.4 & 26 & 2261 & 812 & 0.9 & 0.34 & 0.17 \\
\hline 3 & RTS03 & 8.9 & 25 & 2749 & 634 & 2.5 & 0.20 & 0.14 \\
\hline 4 & RTS04 & 8.7 & 23 & 2518 & 807 & 2.1 & 0.13 & 0.10 \\
\hline 5 & RTS05 & 7.9 & 22 & 2834 & 552 & 3.6 & 0.28 & 0.18 \\
\hline 6 & RTS06 & 7.8 & 26 & 2150 & 416 & 2.4 & 0.25 & 0.17 \\
\hline 7 & RTS07 & 8.8 & 27 & 2417 & 632 & 1.1 & 0.23 & 0.18 \\
\hline 8 & RTS08 & 9.5 & 22 & 2981 & 891 & 3.0 & BDL & - \\
\hline 9 & RTS09 & 8.6 & 23 & 2015 & 354 & 2.8 & 0.15 & 0.13 \\
\hline 10 & RTS10 & 8.2 & 27 & 2206 & 428 & 1.5 & 0.30 & 0.25 \\
\hline 11 & RTS11 & 7.1 & 25 & 2148 & 219 & 0.7 & BDL & - \\
\hline 12 & RTS12 & 7.9 & 24 & 2731 & 587 & 1.8 & 0.32 & 0.15 \\
\hline 13 & RTS13 & 8.0 & 23 & 2658 & 453 & 2.1 & 0.19 & 0.17 \\
\hline 14 & RTS14 & 7.4 & 22 & 1860 & 497 & 2.7 & BDL & - \\
\hline 15 & RTS15 & 7.9 & 27 & 2569 & 692 & 2.6 & 0.33 & 0.26 \\
\hline 16 & RTS16 & 8.4 & 25 & 2933 & 641 & 1.9 & 0.12 & 0.10 \\
\hline 17 & RTS17 & 8.6 & 26 & 2413 & 573 & 2.0 & 0.20 & 0.14 \\
\hline 18 & RTS18 & 7.5 & 24 & 1964 & 295 & 1.1 & 0.27 & 0.22 \\
\hline 19 & RTS19 & 7.6 & 22 & 1582 & 216 & 0.8 & BDL & - \\
\hline 20 & RTS20 & 7.3 & 24 & 1846 & 268 & 1.0 & 0.19 & 0.15 \\
\hline
\end{tabular}


different water samples respectively. Thus it shows that the biomass of $B$. subtilis can be used as an efficient biosorbent for metal ion removal from real wastewater.

\section{CONCLUSION}

The present research evaluates that $B$. subtilis biomass is potential in removing $\mathrm{Pb}(\mathrm{II})$ ions from water sources. Pretreatment with different chemicals enhanced the biosorption efficiency of B. subtilis biomass. Among various chemical treatments, the biomass treated with formaldehyde showed the highest efficiency of $80.92 \%$. The maximum biosorption efficiency obtained by the control and treated biomass of B. subtilis was $58.04 \%$ and $89.8 \%$ attained with the optimized experimental conditions: initial $\mathrm{Pb}(\mathrm{II})$ ion concentration of $50 \mu \mathrm{g} / \mathrm{mL}$, biosorbent dose of $1.5 \mathrm{~g}, \mathrm{pH} 6.5$ at $35^{\circ} \mathrm{C}$ with contact time of $16 \mathrm{~h}$ at $40 \mathrm{rpm}$. SEM-EDX analysis shows the bulging of cells and a peak for $\mathrm{Pb}$ (II) in the spectrum as a result of biosorption. FTIR evaluates that carboxyl, hydroxyl, and amino functional groups are involved in biosorption. Kinetic data were fitted better with the pseudo second-order model for both control and treated biomass of $B$. subtilis. From the results, we can conclude that the formaldehyde treated biomass of $B$. subtilis can be used as a cost-effective biosorbent for the removal of metal ions from contaminated water resources.

\section{ACKNOWLEDGEMENTS}

The authors would like to thank SMS Labs, Chennai for their support on ICP-OES analysis and Center for Nano science and Nanotechnology, Satyabhama University, Chennai for SEM-EDX analysis.

\section{LITERATURE CITED}

1. Wang, J. \& Chen, C. (2006). Biosorption of Heavy Metals by Saccharomyces Cerevisiae: A Review. Biotechnol. Adv. 24(5), 427-451. DOI: 10.1016/j.biotechhadv.2006.03.001.

2. Al-Garni, S.M. (2005). Biosorption of Lead by Gram-Ve Capsulated and Non-Capsulated Bacteria. Water Sa. 31(3), 345-350. DOI: 10.4314/wsa.v31i3.5224.

3. El-Naggar, N.E.-A., Hamouda, R.A., Mousa, I.E., Abdel-Hamid, M.S. \& Rabei, N.H. (2018). Biosorption Optimization, Characterization, Immobilization and Application of Gelidium Amansii Biomass for Complete $\mathrm{Pb} 2+$ Removal from Aqueous Solutions. Sci. Rep. 8(1), 13456-13475. DOI: 10.1038/s41598018-31660-7.

4. Organization, W.H. (2004) Guidelines for Drinking-Water Quality, vol 1. World Health Organization.

5. Barakat, M. (2011). New Trends in Removing Heavy Metals from Industrial Wastewater. Arab. J. Chem. 4(4), 361-377. DOI: 10.1016/j.arabjc.2010.07.019.

6. Volesky, B. \& Kratochvil, D. (1998). Advances in the Biosorption of Heavy Metals. Trends Biotechnol. 16, 291-300. DOI: 10.1016/S0167-7799(98)01218-9.

7. Volesky, B. \& Holan, Z. (1995). Biosorption of Heavy Metals. Biotechnol. Prog. 11(3), 235-250. DOI: 10.1012/ bp00033a001.

8. Lan, T., Ding, C.-C., Liao, J.-L., Li, X.-L., Li, X.-L., Zhang, J., Zhang, D., Yang, J.-J., Luo, S.-Z. \& An, Z. (2015). Biosorption Behavior and Mechanism of Thorium on Bacillus Sp. Dwc-2 Isolated from Soil. Nucl. Sci. Tech. 26(6), 060301-060311. DOI: 10.13538/j.1001-8042/nst.26.060301.

9. Al-Homaidan, A., Al-Houri, H., Al-Hazzani, A. \& Moubayed, M. (2014). Biosorption of Copper Ions from Aqueous
Solutions by Spirulina Platensis Biomass. Arab. J. Chem. 7, 57-62. DOI: 10.1016/j.arabjc.2013.05.022.

10. Gulati, R., Saxena, R. \& Gupta, R. (2002). Fermentation Waste of Aspergillus Terreus: A Potential Copper Biosorbent. World J. Microbiol. Biotechnol. 18(5), 397-401. DOI: 10.1023/A:1015540921432.

11. Rodríguez-Tirado, V., Green-Ruiz, C. \& Gómez-Gil, B. (2012). $\mathrm{Cu}$ and $\mathrm{Pb}$ Biosorption on Bacillus Thioparans Strain U3 in Aqueous Solution: Kinetic and Equilibrium Studies. Chem. Eng. J. 181, 352-359. DOI: 10.1016/j.cej.2011.11.091.

12. Hasan, S.H. \& Srivastava, P. (2009). Batch and Continuous Biosorption of $\mathrm{Cu} 2+$ by Immobilized Biomass of Arthrobacter Sp. J. Environ. Manag. 90(11), 3313-3321. DOI: 10.1016/j. jenvman.2009.05.005.

13. Gupta, R., Saxena, R., Mohapatra, H. \& Ahuja, P. (2002) Microbial Variables for Bioremediation of Heavy Metals from Industrial Effluents. In: Prog. Ind. Microbiol. 36, 189-229. DOI: 10.1016/S0079-6352(02)80012-1.

14. Olmos, J. \& Paniagua-Michel, J. (2014). Bacillus Subtilis a Potential Probiotic Bacterium to Formulate Functional Feeds for Aquaculture. Microb. Biochem. Technol. 6(7), 361-365. DOI: 10.4712/1948-5948.100169.

15. Tarangini, K. \& Satpathy, G.R. (2009). Optimization of Heavy Metal Biosorption Using Attenuated Cultures of Bacillus Subtilis and Pseudomonas Aeruginosa. J. Environ. Res. Dev. 3(3), 677-684.

16. Sabae, S., Hazaa, M., Hallim, S., Awny, N. \& Daboor, S. (2006). Bioremediation of $\mathrm{Zn}, \mathrm{Cu}$ and $\mathrm{Fe}$ Using Bacillus Subtilis D215 and Pseudomonas Putida Biovar Ad 225. Biosci. Res. 3(1), 189-204.

17. Upasana, S., Singh, B. \& Singh, K. (2012). Lead Removal from Aqueous Solutions by Bacillus Subtilis. J. Chem. Pharm. Res. 4(4), 2242-2249.

18. Syed, S. \& Chinthala, P. (2015). Heavy Metal Detoxification by Different Bacillus Species Isolated from Solar Salterns. Scientifica. 2015, 1-8. DOI: 10.1155/2015/319760.

19. Çolak, F., Atar, N., Yazıcıoğlu, D. \& Olgun, A. (2011). Biosorption of Lead from Aqueous Solutions by Bacillus Strains Possessing Heavy-Metal Resistance. Chem. Eng. J. 173(2), 422-428. DOI: 10.1016/j.cej.2011.07.084.

20. Qu, J., Zang, T., Gu, H., Li, K., Hu, Y., Ren, G., Xu, X. \& Jin, Y. (2015). Biosorption of Copper Ions from Aqueous Solution by Flammulina Velutipes Spent Substrate. BioResour. 10(4), 8058-8075. DOI: 10.15376/biores.10.4.8058-8075.

21. Joo, J.-H., Hassan, S.H. \& Oh, S.-E. (2010). Comparative Study of Biosorption of $\mathrm{Zn} 2+$ by Pseudomonas Aeruginosa and Bacillus Cereus. Int. Biodeterior. Biodegr. 64(8), 734-741. DOI: 10.1016/j.ibiod.2010.08.007.

22. Patel, R. \& Chandel, M. (2015). Effect of Ph and Temperature on the Biosorption of Heavy Metals by Bacillus Licheniformis. Int. J. Sci. Res. 4(1), 2272-2275.

23. Hou, Y., Cheng, K., Li, Z., Ma, X., Wei, Y., Zhang, L. \& Wang, Y. (2015). Biosorption of Cadmium and Manganese Using Free Cells of Klebsiella Sp. Isolated from Waste Water. Plos one. 10(10), e0140962. DOI: 10.1371/journal.pone.0140962.

24. Das, N., Charumathi, D. \& Vimala, R. (2007). Effect of Pretreatment on $\mathrm{Cd} 2+$ Biosorption by Mycelial Biomass of Pleurotus Florida. Af. J. Biotechnol. 6(22), 2555-2558. DOI: 10.4314/ajb.v6i22.58137.

25. Yan, G. \& Viraraghavan, T. (2000). Effect of Pretreatment on the Bioadsorption of Heavy Metals on Mucor Rouxii. Water Sa Pretoria. 26(1), 119-124.

26. Hanbali, M., Holail, H. \& Hammud, H. (2014). Remediation of Lead by Pretreated Red Algae: Adsorption Isotherm, Kinetic, Column Modeling and Simulation Studies. Green Chem. Lett. Rev. 7(4), 342-358. DOI: 10.1080/17518253.2014.955062.

27. Çabuk, A., Ilhan, S., Filik, C. \& ÇALIŞKAN, F. (2005). $\mathrm{Pb}(\mathrm{II})$ Biosorption by Pretreated Fungal Biomass. Turk. J. Biol. 29(1), 23-28. 
28. Dadrasnia, A., Chuan Wei, K., Shahsavari, N., Azirun, M. \& Ismail, S. (2015). Biosorption Potential of Bacillus Salmalaya Strain 139si for Removal of Cr (Vi) from Aqueous Solution. Int. J. Environ. Res. Public Health. 12(12), 15321-15338. DOI: 10.3390/ijerph121214985.

29. Suriya, J., Bharathiraja, S. \& Rajasekaran, R. (2013). Biosorption of Heavy Metals by Biomass of Enterobacter Cloacae Isolated from Metal-Polluted Soils. Int. J. Chem. Tech. Res. 5(3), 1229-1238.

30. Oves, M., Khan, M.S. \& Zaidi, A. (2013). Biosorption of Heavy Metals by Bacillus Thuringiensis Strain Osm29 Originating from Industrial Effluent Contaminated North Indian Soil. Saudi J. Biol. Sci. 20(2), 121-129. DOI: 10.1016/j. sjbs.2012.11.006.
31. Masood, F. \& Malik, A. (2011). Biosorption of Metal Ions from Aqueous Solution and Tannery Effluent by Bacillus Sp. Fm1. J. Environ. Sci. Health, Part A. 46(14), 1667-1674. DOI: 10.1080/10934529.2011.623648.

32. Sethuraman, P. \& Dharmendira Kumar, M. (2011). Biosorption Kinetics of $\mathrm{Cu}$ (Ii) Ions Removal from Aqueous Solution Using Bacteria. Pak. J. Biol. Sci. 14(5), 327-335. DOI: 10.3923/pjbs.2011.327.335.

33. Bueno, B., Torem, M., Molina, F. \& De Mesquita, L. (2008). Biosorption of Lead (Ii), Chromium (Iii) and Copper (Ii) by R. Opacus: Equilibrium and Kinetic Studies. Miner. Eng. 21(1), 65-75. DOI: 10.1016/j.mineng.2007.08.013

34. Standard, I. (2006) Methods of Sampling and Test (Physical and Chemical) for Water and Wastewater. IS. 